Jurnal Emik, Volume 4 Nomor 2, Desember 2021

\title{
Adaptasi Kebijakan, Dampak Perkuliahan Daring, dan Strategi Mahasiswa Menjaga Imunitas Tubuh di Masa Pandemi Covid-19
}

\author{
Karmila Kadir \\ Universitas Hasanuddin \\ krmlkdr@gmail.com \\ Nurul Ilmi Idrus \\ Universitas hasanuddin \\ nurulilmiidrus@yahoo.com
}

\begin{abstract}
The world was shocked by a disaster in the form of a very dangerous virus, namely the corona virus or called Covid-19 which requires humans to be able to adapt to this Covid-19 pandemic situation, including in the field of education. At the higher educational level, the learning system changes from face-to-face learning to online learning. This article discusses how students adapt in relation to various policies, the impact of online learning, and students' strategies in maintaining body immunity during the Covid-19 pandemic.

Using a qualitative approach, this research was conducted in the city of Makassar, South Sulawesi Province. Data was collected using in-depth interview and observation. Those who participated in this study were 20 students, consisting of 15 males and five females, whose age ranging between 19 and 22 years. They come from various public and private campuses in the city of Makassar.

The results of the study show that during the Covid-19 pandemic, students experienced many changes. Students themselves adapted to various emerging policies related to Covid19, which include not only government and lecturing policies, but also internal student organization policies. For students, online lectures have impacted not only on the learning process, but also on student health. Various strategies were carried out by students in an effort to maintain body immunity in the midst of the Covid-19 pandemic policy, namely complying with health protocols; implementing a healthy lifestyle; managing stress; and taking supplements. It is argued in this articles that in order to prevent the spread of Covid19, students adapt to the conditions that occur during the Covid-19 pendemic and apply related strategie. Lecturers also need to create a friendly environment and creative method of teaching, so that students can enjoy online learning on that limited screen.
\end{abstract}

Keywords: Students, pandemic, Covid-19, adaptation, impact, and strategy.

\section{Pendahuluan}

Saat ini dunia telah digemparkan oleh adanya bencana dalam bentuk virus yang sangat berbahaya yaitu corona virus atau disebut dengan Covid-19 yang mengharuskan manusia untuk bisa beradaptasi dengan situasi pandemi Covid-19 ini. Corona virus atau yang dikenal dengan sebutan Covid-19 adalah sebuah infeksi penyakit yang disebabkan oleh jenis virus terbaru yang ditemukan pada tahun 2019 (Luzi dan Radaelli 2020:760). Virus ini ditularkan melalui tiga media, yaitu hidung, mulut, dan mata, dan berkembang di paru-paru. Tanda-tanda 
seseorang terkena Covid-19 adalah suhu tubuh naik, demam, mati rasa, batuk, nyeri di tenggorokan, kepala pusing, susah bernafas jika virus corona sudah sampai paru-paru (Syafrida dan Hartati 2020:496).

Menurut Nurkholis (dalam Farah dan Nasution 2020:24), bahwa "salah satu contoh upaya yang dilakukan oleh pemerintah di berbagai belahan dunia adalah dengan menerapkan kebijakan terkait, seperti melakukan lockdown, karantina wilayah, dan pembatasan kontak fisik, terutama bagi daerah yang sudah dikategorikan masuk ke dalam zona merah". Berbagai kebijakan dilakukan oleh pemerintah sebagai bentuk upaya pencegahan Covid-19 yang setiap harinya memakan banyak jiwa. Ini dimulai dari himbauan untuk tinggal di rumah saja (\#dirumahaja), dengan cara bekerja dari rumah atau work from home (WFH), bersekolah dari rumah, beribadah dari rumah, dll. Lalu muncul kebijakan social distancing yang kemudian berubah menjadi physical distancing. Perubahan itu dilakukan karena kata social dianggap kurang tepat sehingga diganti dengan jarak fisik dengan tujuan setiap orang tetap bisa berkomunikasi, namun dengan menjaga jarak fisik setidaknya satu meter. Pemberlakuan kebijakan dilaksanakan dalam upaya mencegah dan memutus mata rantai penyebaran Covid-19. Dalam konteks ini masyarakat harus beradaptasi dengan situasi dan kondisi tersebut agar tetap survive dan dapat kembali menghadapi kehidupan secara normal.

Pola adaptasi yang dijadikan tatanan baru di dalam masyarakat adalah dengan diterapkannya adaptasi kebiasaan baru (AKB), yaitu masyarakat tetap harus waspada terhadap potensi penyebaran Covid-19 di ruang publik. Dalam adaptasi kebiasaan baru, adaptasi yang dilakukan masyarakat untuk pencegahan agar tidak terinfeksi Covid-19 yang menjadi standar prilaku adalah dengan pola $3 \mathrm{M}$, yakni menggunakan masker ketika berada di ruang publik, menjaga jarak dengan orang lain, dan membatasi kerumunan secara bersamaan dalam satu tempat (Zaenudiin dkk. 2021:3). Adaptasi kebiasaan baru merupakan salah satu strategi pencegahan penularan Covid-19 melalui penerapan protokol kesehatan dan hidup produktif di tengah pandemi ini.

Sebagai bentuk upaya agar terhindar dari penularan Covid-19 pemerintah menghimbau masyarakat untuk selalu menjaga kebersihan dan menjalani pola hidup sehat. Pola hidup sehat dilakukan dengan cara berolahraga yang berdasarkan pada FITT (frequence, intensity, time, and type) (Burnet dkk. 2020:229). Selain itu, "masyarakat disarankan untuk menjaga asupan nutrisi dan hidrasi, memerhatikan recovery tubuh sebab tubuh yang lelah akan mudah terserang berbagai macam virus dan penyakit" (Simpson dan Katsanis dalam Kunjung dkk. 2020:725). Dalam pelaksanaan kebijakan yang dianjurkan pemerintah, berbagai bentuk upaya pencegahan atau langkah antisipatif untuk memutus mata rantai penyebaran Covid-19 dilakukan, mulai dari 3M (memakai masker, mencuci tangan, menjaga jarak), memperbanyak minum air putih, menjaga kebersihan, menjaga imunitas tubuh, menghindari kerumunan, meminimalkan keluar rumah, dll.

Berbagai permasalahan yang terjadi akibat Covid-19 dan efek yang ditimbulkan telah mengubah kehidupan dalam berbagai bidang, seperti; ekonomi, perdagangan, pariwisata, komunikasi, interaksi sosial, termasuk pendidikan. Dalam kaitan dengan pendidikan, misalnya, dengan pembatasan interaksi (seperti menjaga jarak, PSBB) berdampak pada pola pembatasan aktivitas manusia dalam melaksanakan perkuliahan, yakni dari perkuliahan dengan sistem tatap muka menjadi perkuliahan dengan sistem pembelajaran online atau pembelajaran di dalam jaringan (daring). 
Jurnal Emik, Volume 4 Nomor 2, Desember 2021

Temuan Sadikin dan Hamidah (2020) menunjukkan bahwa pembelajaran daring berkontribusi terhadap social distancing dan meminimalisir munculnya keramaian mahasiswa, sehingga dianggap dapat mengurangi potensi penyebaran Covid19. Namun, pembelajaran daring mengakibatkan terjadinya peningkatan frekuensi kebiasaan mahasiswa dalam mengoperasikan smartphone dalam waktu yang lama. Menurut Ashadi (dalam Kunjung dkk. 2020:714-715) "rata-rata mahasiswa melakukan video conference dengan dosen mata kuliah selama tiga sampai empat jam per hari. Selama menjalani masa physical distancing di rumah, mahasiswa banyak mengisi waktu mereka untuk bermain smartphone sambil duduk atau berbaring di kasur rata-rata lima jam dalam sehari". Hal tersebut dapat berdampak pada turunnya imunitas tubuh karena kurangnya gerak, mahasiswa cenderung lebih banyak melakukan aktivitas menetap, yaitu lebih banyak duduk dibandingkan dengan bergerak selama perkuliahan online. Padahal menurut Wong dkk. (2020:41), aktivitas fisik dapat dilakukan di dalam rumah dengan berbagai kegiatan fisik dengan intensitas sedang, misalnya jalan di dalam rumah, latihan kekuatan, kelenturan, daya tahan jantung paru serta kombinasi olahraga tersebut.

Prasetyo dan Mayasari (dalam Gumantan dkk. 2020:20) mengemukakan bahwa "imunitas merupakan respon tubuh terhadap bahan asing, baik secara molekuler maupun seluler yang mekanismenya terbagi menjadi imun immunity dan adaptive immunity". Umumnya studi-studi tentang beradaptasi dan menjaga imunitas tubuh di masa pandemi Covid19 berfokus pada penerapan protokol kesehatan dan peningkatan imun yang diperoleh dengan latihan fisik dan memenuhi asupan nutrisi (Nugroho dkk. 2021; Adijaya dan Bakti 2021; Furkan dkk. 2021).
Studi Nugroho dkk. (2021) tentang kesiapan adaptasi kebiasaan baru untuk pencegahan penularan Covid-19 yang dilakukan di Desa Bumirejo, Kecamatan Mungkid, Kabupaten Magelang menunjukkan bahwa adaptasi yang dilakukan berupa pelatihan cuci tangan dengan sabun, pembuatan handsanitizer, senam bersama, dan pemanfaatan tanaman obat keluarga (TOGA). Dalam studinya tentang peningkatan sistem imunitas tubuh saat menghadapi pandemi Covid-19, temuan Adijaya dan Bakti (2021) menunjukkan bahwa peningkatan imunitas dapat diperoleh dengan melakukan latihan fisik secara rutin dan teratur serta memakan makanan yang bergizi. Selaras dengan temuan Furkan dkk. (2021) tentang bagaimana menjaga daya tahan tubuh di masa pandemi Covid-19 bahwa mereka menjaga kebersihan, mengomsumsi makanan sehat, berolahraga, memeriksa diri sendiri, dan memenuhi kebutuhan cairan tubuh.

Sejauh ini literatur yang ada tentang dampak pembelajaran daring terhadap mahasiswa lebih terfokus pada dampak psikologis (Asti 2021; Argaheni 2020; Pustikasari dan Fitriyanti 2920; Hasanah dkk. 2020), sementara dampak kesehatan dari segi fisik (jikapun) ada masih terbatas, artikel ini mengisi celah tersebut. Selain itu, jika studi-studi sebelumnya menitikberatkan pada bagaimana masyarakat beradaptasi dengan melakukan aktivitas fisik dan non-fisik sebagai bentuk upaya pencegahan terhadap Covid-19 (Furqan dkk 2021; Adijaya dan Bakti 2021; Nugroho dkk. 2021; Burnett 2020), literatur terkait dengan bagaimana beradaptasi dengan berbagai kebijakan terkait kurang tersentuh.

Pembahasan pada artikel ini dibagi atas tiga sesi. Bagian pertama mengeksplorasi bagaimana adaptasi mahasiswa dengan berbagai kebijakan terkait pandemi Covid-19. Pembahasan pada bagian kedua 
Adaptasi Kebijakan, Dampak Perkuliahan Daring, dan Strategi Mahasiswa...

menitikberatkan dampak pembelajaran daring bagi mahasiswa. Bagian ketiga mendiskusikan tentang berbagai strategi yang digunakan oleh mahasiswa dalam upaya menjaga imunitas tubuh di tengah pandemi Covid-19.

\section{Metode Penelitian}

Penelitian dengan menggunakan pendekatan kualitatif ini dilakukan di Kota Makassar, Provinsi Sulawesi Selatan atas pertimbangan bahwa kota Makassar sebagai salah satu kota metropolitan dan sebagai salah satu pusat pendidikan. Di Kota Makassar terdapat lima perguruan tinggi negeri dan 108 perguruan tinggi swasta yang tersebar di berbagai wilayah. ${ }^{1}$ Selain itu, Kota Makassar telah dua kali menerapkan PSBB.

Pengumpulan data dilakukan melalui pengamatan (observation) dan wawancara mendalam (in-depth interview). Observasi dilakukan dengan melihat bagaimana mahasiswa interaksi dan adaptasi mahasiswa pada berbagai kebijakan yang diberlakukan terkait dengan Covid-19. Wawancara mendalam (in-depth interview) dilakukan untuk mengeksplorasi bagaimana mahasiswa beradaptasi di masa pandemi Covid-19 dan strategi apa yang dilakukan dalam menjaga imunitas tubuh di tengah kebijakan pemerintah yang berlaku. Dengan topik wawancara mencakup apa saja kebijakan yang terkait dengan Covid-19, bagaimana mereka menyesuaikan diri dengan kebijakan-kebijakan terkait, dampak kebijakan terkait Covid-19 pada mahasiswa, serta tindakan yang dilakukan sebagai strategi dalam menjaga ketahanan tubuh di tengah pandemi Covid-19.

Informan penelitian berjumlah 20 orang, yang terdiri dari 15 orang laki-laki dan 5 orang perempuan, mereka berusia antara 19 dan 23 tahun, dan berasal dari berbagai kampus negeri maupun swasta di Kota Makassar, sebagaimana dijabarkan dalam Tabel 1 berikut ini:

\begin{tabular}{|c|l|c|c|c|}
\hline \multicolumn{5}{|c|}{ Tabel 1. Informan Penelitian } \\
\hline No. & \multicolumn{1}{|c|}{$\begin{array}{c}\text { Umur } \\
\text { (Tahun) }\end{array}$} & $\begin{array}{c}\text { Jenis } \\
\text { Kelamin }\end{array}$ & Instansi \\
\hline 1. & Muh. Hikma Waldy & 19 & L & UNISMUH \\
\hline 2. & Nindya Praja Panaungi & 19 & L & IPDN Kampus SULSEL \\
\hline 3. & Rio Anugerah & 20 & L & UMI \\
\hline 4. & Ahmad Rianto & 20 & L & PNUP \\
\hline 5. & Alfandi Kafiar & 20 & L & IPDN Kampus SULSEL \\
\hline 6. & Agus Pratama Saputra & 20 & L & UNHAS \\
\hline 7. & Andriansyah Hamzah & 20 & L & UNM \\
\hline 8. & Nur Ali & 21 & L & POLTEKES Makassar \\
\hline 9. & Taufiqqurahman Yunus & 21 & L & UNHAS \\
\hline 10. & A. M. Adnan Kurniawan & 21 & L & UNHAS \\
\hline 11. & Qausa Yanotama Farakhan & 21 & L & IPDN Kampus SULSEL \\
\hline 12. & Bambang & 22 & L & PNUP \\
\hline 13. & Hendra Lesmana & 22 & L & PIP Makassar \\
\hline 14. & Miswar Airlangga & 22 & L & PIP Makassar \\
\hline 15. & Zainal & 23 & L & UIM \\
\hline
\end{tabular}

1

http://www.pendaftaranmahasiswa.web.id/2019/07/da ftar-perguruan-tinggi-negeri-swasta 24.html, diakses tanggal 26 November 2021. 
Jurnal Emik, Volume 4 Nomor 2, Desember 2021

\begin{tabular}{|c|l|c|c|c|}
\hline 16. & Sri Nurwanti & 20 & $\mathrm{P}$ & AKPER Bhayangkara \\
\hline 17. & Syopyanah Sri Puspa & 21 & $\mathrm{P}$ & UMI \\
\hline 18. & Mutmainna Rahma & 21 & $\mathrm{P}$ & UNHAS \\
\hline 19. & Sri Astuti & 21 & $\mathrm{P}$ & UNHAS \\
\hline 20. & Asmilia Amelia & 22 & $\mathrm{P}$ & $\begin{array}{c}\text { Politeknik STIA LAN } \\
\text { Makassar }\end{array}$ \\
\hline
\end{tabular}

Analisis dimulai dengan menggabungkan semua data, baik dari catatan pengamatan hingga data dari transkrip wawancara. Dari hasil penelusuran data ditemukan beberapa topik yang meliputi perubahan perilaku dan aktivitas mahasiswa selama masa pandemi Covid-19, pandangan mahasiswa terhadap kebijakan yang diberlakukan pemerintah sebagai upaya dalam memutus mata rantai Covid-19, dampak dari kebijakan pemerintah terhadap kesehatan mahasiswa, serta strategi mahasiswa dalam menjaga imunitas tubuh di masa pandemi Covid19. Ini dilanjutkan dengan mendeskripsikan data secara sistematis, terorganisir dan tersusun. Ini kemudian dilanjutkan dengan pemaknaan, sebelum akhirnya menarik kesimpulan.

Sebelum memulai wawancara masingmasing calon informan diminta kesediaannya untuk berpartisipasi dalam penelitian ini dengan terlebih dahulu menjelaskan maksud dan tujuan dari penelitian ini. Jika mereka bersedia, maka ini dilanjutkan dengan meminta kesediaan masingmasing untuk direkam pada sesi wawancara. Wawancara dilakukan melalui dua cara, yaitu face to face (tatap muka) dengan mengikuti protokol kesehatan dan kombinasi antara face to face dan chatting (obrolan daring) melalui aplikasi Whatsapp. Dari 20 informan, 19 orang bersedia untuk diwawancarai serta bersedia untuk direkam dan mencantumkan nama aslinya, selebihnya wawancara dilakukan tanpa rekaman

\footnotetext{
${ }^{2}$ https://www.halodoc.com/artikel/mengenalprotokol-kesehatan-5m-untuk-cegah-covid-19, diakses tanggal 1 November 2021.
}

dan menggunakan nama samaran sebagai "Bambang".

\section{Adaptasi Kebijakan di Masa Pandemi}

Adaptasi mahasiswa dalam konteks ini terbagi atas tiga, yaitu adaptasi terhadap kebijakan pemerintah, kebijakan perkuliahan, dan kebijakan organisasi, sebagaimana yang akan didiskusikan berikut ini.

\section{Kebijakan Pemerintah}

Ada beberapa kebijakan yang diberlakukan oleh pemerintah dalam upaya menghambat penyebaran Covid-19. Misalnya, penerapan kebijakan protokol kesehatan 3M (memakai masker, mencuci tangan, menjaga jarak) atau kebijakan terkait yang lebih komprehensif dengan pola 5M (memakai masker, mencuci tangan, menjaga jarak, menjauhi kerumunan, dan mengurangi mobilitas) ${ }^{2}$ tidak hanya itu kebijakan seperti work from home (WFH) juga diterapkan pada era new normal ini. Penerapan pembatasan sosial berskala besar (PSBB) dimana pada pelaksanaanya terbagi atas PSBB Transisi dan PSBB ketat. Kemudian kebijakan pemberlakuan pembatasan kegiatan masyarakat (PPKM), kebijakan ini diterapkan pada 7 provinsi Jawa dan Bali. Sebagai tindak lanjut dari PPKM maka pemerintah mengadakan PPKM Mikro atas pertimbangan bahwa PPKM perlu dilaksanakan dengan teliti di tingkat masyarakat kecil yakni Rukun Tetangga (RT) dan Rukun Warga (RW). 
Pasca 3 minggu setelah lebaran Idul Fitri 2021 kasus positif Covid-19 terjadi peningkatan sebesar 53,4\% ${ }^{3}$. Sehingga pemerintah menerbitkan kebijakan PPKM Darurat yang dimana dalam kebijakan kali ini, pemerintah membagi tiap-tiap wilayah berdasarkan tingkat situasi epidemiologi setempat yang terdiri dari lima level, mulai dari level 0 (terbaik) hingga level 4 (terburuk).

Kebijakan $3 \mathrm{M}$ relatif lebih mudah dilakukan, terutama memakai masker dan mencuci tangan. Ini dapat dilihat dari bagaimana mahasiswa menggunakan masker secara konsisten dan di berbagai ruang publik (kampus, kantor, toko, mall, cafe, restoran, mesjid, dll). Di rumah-rumah disediakan tempat mencuci tangan atau secara pribadi orang menyediakan sendiri handsanitizer-nya masing-masing. Mutmainna 21 (tahun), salah seorang mahasiswa yang konsisten menerapkan 3M dalam setiap aktivitasnya terutama di ruang publik. Bahkan ia mengaku selama pandemi membawa handsanitizer merupakan hal yang wajib. Kebiasaan baru yang ia lakukan yaitu mencuci tangan dengan handsanitizer setelah bersentuhan langsung dengan benda yang tidak terjamin kebersihannya.

Ketika kasus Covid-19 meningkat dan Makassar berstatus zona merah, PSBB diajukan oleh pemerintah Kota Makassar. Berdasarkan Peraturan Menteri Kesehatan No. 9 Tahun 2020, PSBB hanya diberikan izin kepada beberapa daerah dengan jumlah kasus yang tinggi. Penetapan PSBB dilakukan berdasarkan permohonan gubernur/bupati/walikota atau ketua gugus tugas penanganan Covid-19. Permohonanpun harus disertai dengan data peningkatan jumlah dan penyebaran kasus menurut waktu serta kejadian transmisi

https://amp.kompas.com/nasional/read/2021/06/09/15 541041/satgas-tiga-minggu-pasca-lebaran-kasus- lokal. PSBB dilakukan selama masa inkubasi terpanjang, yakni 14 hari. Jika masih terbukti penyebarannya, dapat diperpanjang selama 14 hari sejak ditemukan kasus terakhir. Selain itu, daerah juga harus menyampaikan informasi kesiapan daerah, seperti aspek ketersediaan kebutuhan hidup dasar rakyat, sarana dan prasarana kesehatan, anggaran, serta operasional jaring pengaman sosial dan keamanan.

Kota Makassar termasuk salah satu kota di Indonesia yang telah menerapkan PSBB dan sebanyak dua kali. PSBB pertama didasarkan pada Peraturan Walikota No. 20 Tahun 2020 tentang Pelaksanaan PSBB di Kota Makassar yang diberlakukan mulai minggu ketiga bulan April 2020. Sementara PSBB kedua didasarkan pada Keputusan Walikota No. 1153/360/Tahun 2020 tentang Penetapan Perpanjangan Pemberlakuan Pelaksanaan PSBB di Kota Makassar Provinsi Sulawesi Selatan yang diberlakukan di bulan Mei 2020. Kebijakan-kebijakan yang dikeluarkan untuk menghambat penyebaran Covid-19 berdampak pada berbagai bidang kehidupan.

Sementara untuk menjauhi kerumunan dan mengurangi mobilitas cenderung, pemerintah membuat berbagai kebijakan terkait untuk mengatasinya, seperti menerapkan pembatasan pada berbagai acara, baik itu acara di kantor-kantor, di acara perkawinan, dan acaraacara berkumpul lainnya. Jika dilihat dari segi penerapan kebijakan pemerintah tentang pembatasan sosial berskala besar (PSBB). Dengan kebijakan ini, Hendra (21 tahun), sejumlah fasilitas umum ditutup untuk sementara waktu, seperti masjid, sekolah/kampus, dll. Ini membuatnya melakukan berbagai aktivitas di rumah, seperti shalat yang biasanya rutin ia lakukan berjamaaah di masjid

covid-19-naik-534-persen, diakses tanggal 28 November 2021. 
beralih ke rumah. Hikma (19 tahun), mahasiswa yang sering berkumpul atau nongkrong bersama teman-temannya terpaksa harus berhenti karena beberapa café bahkan mall tempatnya nongkrong diberlakukan jam malam atau bahkan ditutup untuk sementara waktu.

Dalam kaitan dengan pelaksanaan kebijakan pembatasan masyarakat ini, sejumlah kritikan muncul. Asmilia (22 tahun) berpendapat bahwa ini tidak cukup efektif untuk mencapai tujuan karena penerapannya yang tidak cukup merata. la menekankan bahwa saat penerapan kebijakan PSBB, fasilitas-fasilitas umum seperti masjid, sekolah/kampus, kantor, bahkan pusat perbelanjaan ditutup. Akan beberapa fasilitas umum luput dari kebijakan tersebut, misalnya mall yang masih tetap dapat beroperasi. Agus (20 tahun) juga beranggapan bahwa kebijakan PSBB yang diberlakukan di kota Makassar kurang efektif dalam penerapannya, karena kurangnya pengawasan. Pelaksanaan kebijakan PSBB hanya terkesan setengah hati karena masih terdapat beberapa tempat umum seperti café yang masih beroperasi hingga malam hari. Meskipun memuji efektifitas pelaksanaan kebijakan terkait dengan upaya untuk menghambat penyebaran Covid-19, Nur (21 tahun) karena kebijakan PSBB dapat menekan jumlah kasus Covid-19, namun dampaknya sangat signifikan, terutama terhadap golongan menengah ke bawah karena mereka yang berpenghasilan harian kehilangan sumber pendapatan. Kritikan-kritikan ini bukan berarti mereka tidak menyetujui pembatasan tersebut, tapi kebijakan harus diberlakukan tanpa tebang pilih, harus diserta dengan pengawasan, dan harus mengatasi konsekuensi yang ditimbulkan oleh pembatasan tersebut.

\section{Kebijakan Perkuliahan}

Melalui kebijakan program pemerintah yang diwakili Kementerian Kesehatan dan Kementerian Pendidikan dan Kebudayaan
(Kemendikbud) serta penyampaian data dan informasi perkembangan global infeksi Covid-19 dari instansi gugus tugas, kampus-kampus di Indonesia (baik perguruan tinggi negeri maupun swasta) telah melakukan penghentian proses kegiatan belajar-mengajar tatap muka dan menghimbau agar perguruan tinggi memantau dan membantu kelancaran para mahasiswanya melakukan pembelajaran dari rumah (study from home) dan menggantinya dengan kuliah daring (Pakpahan dan Fitriani dalam Wijayanti dkk. 2020:32).

Bagi lembaga pendidikan, WFH ini berarti proses kegiatan belajar-mengajar yang biasanya dilakukan di ruang-ruang kelas secara langsung, dialihkan ke sistem pembelajaran online atau dalam jaringan (daring) dan menjadi solusi agar proses belajar-mengajar tetap dapat berlangsung dan tetap menjaga agar tidak terjadi interaksi antar manusia secara langsung (tatap muka). Oleh karenanya, civitas akademika (tenaga pendidik, mahasiswa, dan tenaga kependidikan) sebagai elemen penting dalam proses pembelajaran harus beradaptasi dengan sistem pembelajaran tatap muka ke sistem pembelajaran dalam jaringan (daring).

Aktivitas belajar di rumah dengan media daring menuntut mahasiswa untuk menguasai media yang beragam. Aktivitas perkuliahan online yang beragam mengakibatkan penggunaan media atau aplikasi daring yang beragam demi efektifitas jalannya perkuliahan. Studi Kurniawati dan Baroroh (2016) terhadap 304 mahasiswa di Universitas Muhammadiyah Bengkulu menunjukkan bahwa pemahaman mahasiswa mengenai media digital berada pada kategori sedang; dengan tingkat individual competence mahasiswa dalam meliterasi media digital berada dalam level basic. Ini merupakan hal mendasar dalam aktivitas belajar daring, dimana ketika seorang mahasiswa tidak menggunakan media literasi terhadap teknologi 
Adaptasi Kebijakan, Dampak Perkuliahan Daring, dan Strategi Mahasiswa...

pembelajaran daring, maka aktivitas belajar daring tidak dapat berjalan sebagaimana semestinya. Syopiyana (21 tahun) mengungkapkan, bahwa dalam pembelajaran daring, mahasiswa harus dapat mengoperasikan aplikasi belajar, seperti Zoom, Google Classroom dan Whatsapp karena ini merupakan aplikasi yang banyak digunakan dalam proses belajarmengajar.

Jika merujuk pada apa yang diidentifikasi oleh Nasution tentang prioritas utama dalam menunjang sistem pembelajaran daring, maka ini mencakup: ketersediaan hardware dan software pendukung yang modern; infrastruktur jaringan internet yang memadai; dan kebijakan yang mendukung penerapan virtual class. Selain itu, siswa ataupun mahasiswa juga dituntut untuk memiliki kemampuan dasar dalam penggunaan teknologi, seperti etika online, keterampilan sosial online, mekanisme penelusuran literature web, dll. (Nasution dalam Farah dan Nasution 2020:30). Kebijakan yang diberlakukan pada perkuliahan secara daring mengindikasikan bagaimana perubahan menuntut mahasiswa untuk beradaptasi agar tidak mengalami ketertinggalan dalam hal pembelajaran. Anwar dan Tuhuteru (2020:108-114) mengindikasikan adanya dua faktor penghambat dalam pembelajaran daring, yakni faktor internal (sarana dan prasarana, keuangan mahasiswa, kegagapan teknologi) dan eksternal (ketiadaan perangkat teknologi, ketidakstabilan jaringan internet, dan keterbatasan listrik).

Akan tetapi, menurut Nur (21 tahun) yang merupakan mahasiswa Politeknik Kesehatan (POLTEKES) Makassar, bahwa penerapan kebijakan di bidang pendidikan tidak hanya menghambat penyebaran Covid-19, tetapi juga menghambat pola belajar dari mahasiswa itu sendiri. Ini karena kuliah berbasis daring membuat mahasiswa kehilangan fokus dalam belajar dikarenakan pada penerapannya terdapat berbagai hambatan atau kendala, seperti jaringan yang kurang stabil, tidak adanya teman diskusi secara langsung dan faktor lingkungan yang kurang mendukung, sehingga ini dapat membuat kurangnya konsentrasi pada proses pembelajaran daring. Ini terutama karena kampusnya merupakan kampus vokasi yang lebih banyak berpraktek dibandingkan berteori, sehingga tatap muka menjadi sangat penting dalam proses pembelajaran.

Hal serupa juga dirasakan oleh Bambang (22 tahun), mahasiswa Politeknik Negeri Ujung Pandang (PNUP) yang juga berasal dari kampus yang bergerak di bidang vokasi. Menurutnya kebijakan yang berlaku sudah cukup baik karena keputusan tersebut pasti sudah dipikirkan dengan baik oleh kementrian sebelum diberlakukan. Namun, setiap kebijakan yang berlaku memiliki kekurangan dalam penerapannya, sehingga tidak cukup efektif untuk memenuhi tujuannya. Kebijakan yang diberlakukan pada dunia pendidikan dengan menerapkan perkuliahan secara daring menurutnya cukup menghambat proses pembelajaran dikarenakan adanya kendala, seperti jaringan yang tidak cukup stabil dan terbatasnya fasilitas pendukung dalam perkuliahan daring, sehingga pembelajaran tidak terserap, terutama pada kegiatan praktek yang semestinya dilakukan secara luring karena sarana dan prasarananya hanya bisa ditemukan di kampus.

Rio (20 tahun), menceritakan penyesuaian-penyesuaian aktivitas yang dilakukan di masa pandemi Covid-19. Aktivitas belajar yang diterapkan sebelum dan setelah pandemi, mengalami perubahan dari perkuliahan luring atau tatap muka ke perkuliahan daring. Selama pandemi, Rio berusaha menyesuaikan gaya belajarnya yang biasanya jika perkuliahan secara luring mahasiswa dapat berdiskusi secara langsung, 
tetapi pada pelaksanaan perkuliahan daring konsentrasi yang penuh sangat dibutuhkan untuk bisa menerima materi dengan baik. Segala aktivitas perkuliahan dilakukan dari rumah, termasuk untuk kegiatan praktek. Dalam konteks Rio yang menekuni jurusan IImu Hukum, yang dalam proses perkuliahannya terdapat praktek peradilan yang biasanya dilakukan di ruang sidang, kini dialihkan ke ruang virtual. Menurutnya, ini kurang efektif karena mahasiswa menginginkan untuk melakukannya secara langsung di ruang real, sehingga lebih meresapi praktek peradilan itu sendiri (baca, misalnya, Damayanthi 2020).

Hal serupa juga dipertegas oleh Hendra (22 tahun) yang merupakan salah seorang mahasiswa Politeknik Ilmu Pelayaran (PIP) yang telah berada pada semester akhir. Menurutnya, penyesuaian aktivitas yang dialami, yaitu kuliah yang dilakukan secara face to face dengan dosen, konsultasi, bimbingan, seminar, ujian, dll. semuanya dilakukan secara langsung. Sementara di masa pandemi Covid-19, segala aktivitas perkuliahan berubah dari sistem tatap muka (luring), ke sistem dalam jaringan (daring), sehingga tidak ada interaksi langsung antara dosen dan mahasiswa, terutama di masa PSBB. Hal tersebut tidak semata-mata membuat Hendra ketinggalan dalam proses perkuliahan. Ini justru memunculkan pengetahuanpengetahuan baru terkait penggunaan teknologi sebagai bentuk penyesuaian terhadap perkuliahan yang dilakukan secara daring.

Menurut Ahmad (20 tahun), ada penyesuaian perubahan aktivitas selama melakukan perkuliahan daring, yaitu dari segi aktivitas di luar rumah yang sudah kurang dilakukan dan beralih ke rumah, sehingga secara tidak langsung berdampak pada hubungan sosial dengan orang-orang karena terbatasnya interaksi yang dilakukan secara langsung. Oleh karenanya, Ahmad menjaga hubungan sosial dengan masyarakat sekitarnya dengan tetap berinteraksi melalui gadget untuk saling bertukar kabar. Ini berkelindan dengan apa yang dinyatakan oleh Nasution (dalam Farah dan Nasution 2020:29-30) bahwa kecenderungan penggunaan teknologi sebagai penunjang pembelajaran online adalah minimnya interaksi yang terjalin di masa depan, apabila pola pembelajaran online terus menerus dilakukan sebagai konsep tunggal dalam suatu negara.

Menurut Husamah (dalam Khasanah dkk. 2020:42), perkuliahan secara daring tidak saja memiliki kelebihan tapi juga kelemahan. Kelebihannya adalah membentuk sifat disiplin secara mental dan formal, memberikan kemudahan bagi penguatan, proses penilaian oleh dosen menjadi lebih optimal, dan interaksi antar mahasiswa atau peserta didik dapat secara langsung diamati oleh dosen, terutama dalam proses menerima/mendengarkan materi. Namun, kelemahan dari sistem belajar daring juga cukup signifikan karena misalnya proses pembelajaran menjadi kaku; proses pembelajaran menjadi monoton dan klasik, sehingga menimbulkan kebosanan dan kejenuhan; pembejalaran yang hanya berlaku satu arah menciptakan peluang untuk menurunnya daya kreativitas serta inovasi mahasiswa. Namun, ini sangat tergantung pada bagaimana individu merespon terhadap perubahan tersebut.

\section{Kebijakan Organisasi Mahasiswa}

Pandemi tidak hanya berpengaruh pada sistem perkuliahan melainkan juga aktivitas organisasi mahasiswa. Sebagai organisasi yang harus tetap eksis di masa pandemi Covid-19. Oleh karenanya, pengelolaan organisasi harus adaptif terhadap situasi. Organisasi bagi mahasiswa menjadi salah satu bekal soft skill selain dari pendidikan yang diperoleh melalui proses belajar-mengajar di program studi tempatnya bernaung. Aktif dalam 
Adaptasi Kebijakan, Dampak Perkuliahan Daring, dan Strategi Mahasiswa...

organisasi kampus juga dapat memberi pelajaran tentang kehidupan, terutama yang terkait dengan tata kelola waktu antara kegiatan perkuliahan dan organisasi.

Di masa pandemi Covid-19 ini, pengelolaan organisasi dilakukan secara daring dari masing-masing rumah anggota organisasi. Beberapa bulan di awal masa pandemi Covid-19, pengelolaan organisasi disesuaikan dengan kondisi yang mengharuskan menggunakan sistem daring dalam berkomunikasi antar anggota. Semua perencanaan yang awalnya dilakukan secara tatap muka, kemudian dilaksanakan secara daring. Hal ini juga menyebabkan pengelolaan dan pengawasan menjadi sedikit terhambat.

Asmilia (22 tahun), salah seorang mahasiswi yang turut merasakan penyesuaian kebijakan pada organisasi, mengatakan bahwa setiap aktivitas organisasi normalnya dilakukan secara tatap muka, baik itu kegiatan rapat, sosialisasi dsbnya. Selama pandemi Covid-19, meskipun sempat vakum karena kebijakan PSBB, mereka perlahan beradaptasi dengan beraktivitas secara daring. Menurutnya, seluruh kegiatan yang telah direncanakan disesuaikan dengan situasi pandemi. Pada pelaksanaanya beberapa kegiatan yang masih bisa dilakukan di lapangan tetap dijalankan, sisanya dilakukan melalui aplikasi pertemuan virtual melalui aplikasi Zoom dan Google Meets. Mutmainna (22 tahun) menganggap kebijakan yang berlaku berdampak pada kurangnya aktivitas organisasi yang menyebabkan tidak lancarnya pelaksanaan program kerja internal (seperti pengkaderan yang bertujuan untuk memperkenalkan mahasiswa baru dengan dunia perkuliahaan), maupun eksternal (menjalin hubungan dengan organisasi di luar kampus).

Berbeda dengan yang lainnya, pengalaman Sri (21 tahun) dalam menjalankan organisasi di tengah pandemi Covid-19 bukan sekedar perihal pengelolaan organisasi, melainkan bagaimana ia dapat memotivasi mahasiswa yang merasa jenuh akibat pengelolaan organisasi yang dilakukan secara daring. Ini karena di masa pandemi Covid-19 tidak sedikit mahasiswa yang lalai terhadap tanggung jawabnya sebagai pengurus dan anggota organisasi dan ini berpengaruh pada capaian tujuan organisasi. Hal serupa juga dikeluhkan oleh Andriansyah (20 tahun), bahwa di masa pandemi ia merasa ia tidak saja kesulitan dalam mengelola organisasi, tapi juga dalam penggalangan dana untuk menjalankan program. Biasanya ia dan teman-temannya menjual minuman dan makanan kepada mahasiswa di sekitar kampus dengan cara berkeliling. Namun, hal ini tak lagi dapat dilakukan karena kampus sepi karena kebijakan study from home. Penggalangan dana kemudian dilakukan melalui media sosial Instagram dengan sistem paid promote.

Dalam pelaksanan program organisasi, beberapa langkah teknis yang diambil berupa penundaan pelaksanaan beberapa program kerja, perubahan konsep kegiatan, bahkan peniadaaan beberapa program kerja sebagai pilihan terakhir yang didasarkan pada pertimbangan yang matang. Dalam penerimaan mahasiswa baru, misalnya, organisasi kampus berupaya untuk tetap menjalankan pengkaderan sebagai bentuk penyambutan kehadiran mahasiswa baru. Para pengurus menyesuaikan pelaksaan penerimaan mahasiswa baru dengan kebijakan yang berlaku. Pengkaderan dilakukan secara daring, berlangsung lancar, dan memenuhi capaian program tersebut.

\section{Dampak Perkuliahan Daring Terhadap Mahasiswa}

Kajian literatur yang dilakukan oleh Argaheni (2020) menunjukkan bahwa pembelajaran daring memiliki sejumlah dampak terhadap 
mahasiswa, yakni membingungkan mahasiswa; mahasiswa menjadi pasif, kurang kreatif dan produktif; penumpukan informasi/konsep pada mahasiswa kurang bermanfaat; mahasiswa mengalami stress, dan terjadinya peningkatan kemampuan literasi bahasa mahasiswa. Dalam konteks penelitian ini, berbagai dampak yang dialami mahasiswa yang tidak saja terkait dengan proses pembelajaran, tapi juga berhubungan dengan kesehatan mahasiswa itu sendiri, sebagaimana yang akan dibahas berikut ini.

\section{Proses Pembelajaran}

Pembelajaran daring merupakan sistem pembelajaran yang dilakukan dengan tidak bertatap muka langsung, tetapi menggunakan platform yang dapat membantu proses belajar mengajar yang dilakukan secara jarak jauh (lihat Gambar 1). Tujuan dari adanya pembelajaran daring ialah memberikan layanan pembelajaran bermutu dalam jaringan yang bersifat masif dan terbuka untuk menjangkau peminat ruang belajar agar lebih banyak dan lebih luas (Sofyana dan Rozak, 2019:82). Meskipun pembelajaran daring tidak sepenuhnya baru dalam proses belajar mengajar, pembelajaran daring membutuhkan adaptasi dan usaha agar dapat berjalan dengan lancar. Adapun dampak perkuliahan daring dalam hubungan dengan proses pembelajaran mencakup kesiapan mahasiswa, penumpukan tugas, interaksi antara mahasiswa dan dosen, dan infrastruktur penunjang pembelajaran yang tidak mamadai.

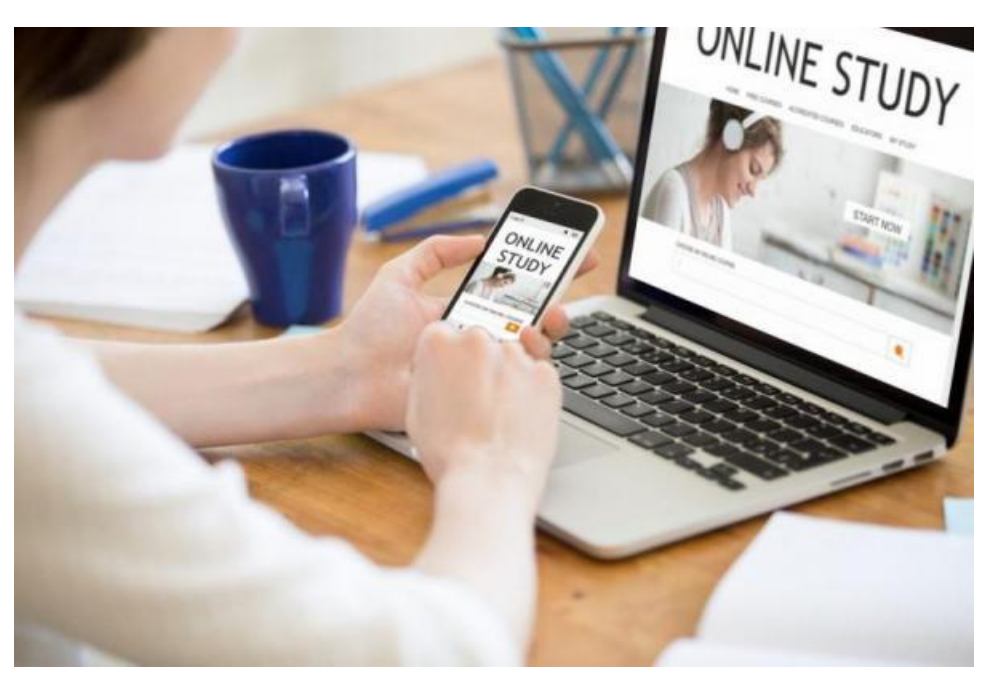

Gambar 1. Ilustrasi Pembelajaran Daring ${ }^{4}$

Di awal perkuliahan daring, banyak mahasiswa yang belum memahami penggunaan media pembelajaran seperti Zoom, Google Classroom, atau aplikasi lain yang digunakan oleh kampus, sehingga hal ini membingungkan mahasiswa. Belum lagi jika perangkat lunak (seperti handphone atau laptop) yang dimiliki ahasiswa tidak mendukung untuk dijadikan sebagai media pembelajaran. Hal ini dialami oleh Hikma (19 tahun), bahwa kendala yang ia alami selama awal perkuliahan daring adalah pada keterbatasan sarana dan prasarana yang dimiliki. Dalam hal ini laptop yang dimiliki tidak kompatibel dengan platform pembelajaran,

\footnotetext{
${ }^{4}$ https://www.jurnas.com/artikel/69198/SistemBelajar-Daring-Masih-Asing-bagi-Guru/, diakses tanggal 10 Desember 2021.
} 
Adaptasi Kebijakan, Dampak Perkuliahan Daring, dan Strategi Mahasiswa...

sehingga ia tidak dapat mengakses aplikasi pembelajaran daring. Hal berbeda diungkapkan oleh Taufiqurahman (21 tahun), bahwa proses pembelajaran perkuliahan daring justru lebih memotivasinya karena ketertarikannya terhadap teknologi, sehingga ia lebih santai dalam menggunakan perangkat digital untuk perkuliahan.

Masalah yang muncul bukan hanya terkait soal keterampilan penggunaan teknologi, tetapi juga berhubungan dengan beban kerja yang besar. Banyak mahasiswa yang mengeluhkan tugas yang banyak dari dosen tanpa adanya materi yang cukup dari dosen pengampu mata kuliah, sehingga mereka agak kewalahan dalam mengikuti proses pembelajaran. Bahkan ada dosen yang hanya memberikan tugas tanpa mengajar dan menjadikan tugas sebagai pengganti perkuliahan. Ini membuat mahasiswa semakin kehilangan arah dan stress (baca, misalnya, Argaheni 2020:105). Syopiyana (21 tahun), misalnya, mengeluhkan bahwa sistem pembelajaran daring membuatnya kehilangan minat belajar, dan ini berdampak pada nilai yang diperolehnya. Ini berbeda dengan Asmilia (22 tahun) yang lebih berfikir positif dalam menyikapi pembelajaran daring. la mengatakan bahwa dalam proses pembelajaran daring tugas yang diberikan oleh dosen semakin banyak, sehingga ia berusaha untuk memenej waktunya agar tidak mengalami ketertinggalan atau menumpuk tugas-tugas hingga mendekati deadline, ketimbang mengeluhkan kondisi pembelajaran daring itu sendiri.

$$
\text { Pembelajaran daring dinilai oleh }
$$
mahasiswa lebih membosankan dari pada pembelajaran di luar jaringan (luring) atau kuliah tatap muka karena mahasiswa dan dosen tidak dapat berinteraksi secara langsung. Menurut Kahfi (2020), ini karena proses pembelajaran tidak hanya berkaitan dengan transfer pengetahuan, tapi juga harus ada interaksi timbal balik antara peserta didik dan tenaga pendidik yang dinamis. Kebosanan ini terjadi karena mahasiswa terbiasa dengan pembelajaran tatap muka secara regular yang lebih interaktif dan komunikatif, sementara dengan sistem pembelajaran daring, mahasiswa merasa kehilangan sense of interaction, sehingga mereka menganggap perkuliahan daring membosankan. Agus (20 tahun) misalnya, beranggapan bahwa perkuliahan daring yang dilakukan menggunakan platform seperti Google Meet, Zoom dan Google Classroom terlalu monoton dan membosankan jika dilakukan dalam waktu yang cukup lama. Hikma (19 tahun), mengeluhkan metode belajar yang diberikan dosen-dosennya yang membosankan karena materi yang disampaikan hanya seputar persentase power point. la mengharapkan adanya perubahan metode belajar yang bervariasi, seperti melalui audio-visual, sehingga dapat menghilangkan rasa bosan sekaligus meningkatkan motivasi belajar.

Selama pandemi Covid-19, perkuliahan yang dilakukan secara daring harus ditunjang terutama oleh ketersediaan kuota dengan jaringan yang baik (baca, misalnya, Anwar 2020; Sadikin dan Hamidah 2020; Damayanthi 2020). Di awal terjadinya pandemi Covid-19 memang mahasiswa tidak ditunjang dengan subsidi kuota. Padahal mahasiswa menghabiskan banyak kuota untuk dapat mengikuti perkulihan daring tersebut.

Kebutuhan kuota kemudian direspon oleh Menteri Pendidikan dan Kebudayaan Riset dan Teknologi (Mendikbudristek), Nadiem Anwar Makarim, dengan meresmikan kebijakan bantuan kuota data internet tahun 2020 pada tanggal 24 September 2020 secara virtual. Peresmian disaksikan langsung secara virtual oleh Menteri Komunikasi dan Informatika (Menkominfo) Johnny G. Plate, Menteri Badan 
Jurnal Emik, Volume 4 Nomor 2, Desember 2021

Usaha Milik Negara (BUMN) Erick Thohir, dan para Direksi operator seluler yang ada di Indonesia yakni Telkomsel, Indosat Ooredoo, XL Axiata, AXIS, 3 (Tri), dan Smartfren. Pelaksanaan kebijakan merupakan hasil koordinasi antara Kemendikbud dengan pemangku kepentingan lainnya yakni Komite Penanganan Covid-19 dan Pemulihan Ekonomi Nasional (KPC PEN), Kementerian Badan Usaha Milik Negara (BUMN), serta Kementerian Komunikasi dan Informatika (Kemenkominfo). ${ }^{5}$ Kebijakan bantuan kuota ini masih terus berlangsung hingga kini. ${ }^{6}$

Namun, ketersediaan kuota jika tidak ditunjang oleh jaringan yang baik, terutama bagi mahasiswa yang tinggal di daerah pedesaan yang infrastrukturnya belum mamadai. Umumnya mahasiswa yang berasal dari daerah pulang kampung selama pandemi Covid-19 karena selain menghemat biaya hidup, mereka juga dapat berkumpul dengan keluarga. Dengan infrastruktur yang tidak mamadai di kampung, ini menyulitkan mahasiswa untuk mengakses kelas daring sementara kehadiran di kelas dihitung hanya jika mahasiswa muncul di kelas daring tersebut. Hendra (22 tahun), misalnya, mengeluhkan pemakaian kuota yang meningkat selama perkuliahan daring. Meskipun pemerintah telah memberikan bantuan kuota kepada mahasiswa, ini tetap dianggap tidak mencukupi kebutuhan mereka untuk kuliah secara daring, sehingga mereka tetap harus menambah kuota untuk itu. Ini berarti ada pengeluaran tambahan untuk mahasiswa. Hal serupa juga dikeluhkan Syopiyana (21 tahun), bahwa selama perkuliahan daring pemakaian kuotanya meningkat. Ini dikarenakan pembelajaran daring yang diakses menggunakan

\section{5}

https://www.kemdikbud.go.id/main/blog/2020/09/ke mendikbud-resmikan-kebijakan-bantuan-kuota-datainternet-2020, diakses tanggal 12 Agustus 2021. gadget, dan secara tidak langsung intensitas pemakain gadget berpengaruh pada peningkatan penggunaan media sosial yang ia gunakan di luar keperluan belajar. Oleh karenanya, mahasiswa juga harus mengingat bahwa pemakaian kuota internet yang disubsidi oleh pemerintah tidak semata digunakan untuk perkuliahan daring, tapi mereka juga digunakan untuk pemakaian untuk kebutuhan di luar perkuliahan daring. Oleh karenanya, mahasiswa tidak dapat sepenuhnya mengklaim bahwa kuota yang diberikan tidak mencukupi.

Berbagai uraian diatas menunjukkan bahwa lahirnya kebijakan tentang perubahan metode belajar dari metode luring ke metode memberikan dampak yang sinifikan dalam proses pembelajaran. Mahasiswa merasa dipaksa dan terpaksa untuk menyesuaikan diri dengan sistem pembelajaran yang diterapkan selama pandemi Covid-19.

\section{Kesehatan}

Sejumlah studi menunjukkan bahwa pembelajaran daring berpengaruh terhadap kesehatan mahasiswa (baca, misalnya, Argaheni 2020; Hasanah dkk. 2020; Pustikasari dan Fitriyanti 2020), baik kesehatan psikologis maupun kesehatan fisik. Perubahan proses belajar yang awalnya secara tatap muka (luring), kemudian berubah menjadi online (luring) yang mengandalkan perangkat elektronik dan jaringan yang secara tidak langsung membawa perubahan psikologis tersendiri bagi mahasiswa. Mahasiswa dituntut untuk dapat menyesuaikan diri dengan kondisi yang berubah sebagai dampak dari pandemi Covid-19.

6

https://www.kemdikbud.go.id/main/blog/2021/10/ke mendikbudristek-kembali-salurkan-bantuan-kuotadata-internet-ke-266-juta-penerima, diakses tanggal 15 Oktober 2021. 
Adaptasi Kebijakan, Dampak Perkuliahan Daring, dan Strategi Mahasiswa...

Dalam pembelajaran daring, mahasiswa seringkali mendapat tuntutan yang lebih berat dibanding saat belajar tatap muka, dan ini memengaruhi kesehatan mental mahasiswa. Sri (20 tahun) menjelaskan bahwa selama proses pembelajaran daring tidak ada tempat untuk bersosialisasi secara langsung atau hanya sekedar bertanya kepada teman secara langsung, semua kegiatan yang dilakukan melalui perantara handphone dan ini memengaruhi kesehatan psikologis mahasiswa. Andriansyah (20 tahun) merasakan kejenuhan yang mendalam selama perkuliahan daring berlangsung. la merindukan kuliah tatap muka dan bertemu secara langsung dengan dosen dan teman-teman kuliahnya.

Selain berdampak secara psikologis, kuliah daring juga berdampak pada kesehatan fisik mahasiswa, yakni kesehatan mata dan tubuh. Oleh karena aktivitas perkuliahan hanya dilakukan sebatas melihat layar gawai/gadget, terutama handphone yang luas layarnya sangat kecil, ini membuat jangkauan penglihatan menjadi sangat terbatas. ${ }^{7}$ Zainal (23 tahun), misalnya, mengeluhkan metode pembelajaran daring ini karena telah mengganggu kesehatan matanya. Ini dikarenakan durasi screen time ${ }^{8}$ yang berlebihan menyebabkan kelelahan pada matanya. la merasakan gejala seperti penglihatan yang kabur, penglihatan ganda, hingga menyebabkan sakit kepala.

Gangguan kesehatan secara fisik lainnya adalah kekakuan otot. Sri (20 tahun) mengungkapkan bahwa perkuliahan daring selain berdampak pada kesehatan psikologisnya, ini juga memengaruhi kesehatan fisiknya sebagai mahasiswa. Akibat duduk lama dalam proses pembelajaran, ia sering mengalami nyeri otot,

\footnotetext{
${ }^{7}$ http://ners.unair.ac.id/site/lihat/read/624/dampakpembelajaran-daring-bagi-kesehatan-mata-padamasa-pandemi-covid-19, diakses tanggal 01

Desember 2021.
}

terutama pada bagian punggung dan leher. Ini diperparah apabila ia duduk pada kursi yang tidak memiliki sandaran atau penyangga dalam jangka waktu yang lama.

Namun, bagi Nindya (19 tahun), mahasiswi IPDN, bahwa kebijakan pemerintah dengan perkuliahan daring tidak berdampak pada kesehatan tubuhnya karena sebagai seorang praja, dia dan teman-temannya melaksanakan olahraga mandiri di asrama masing-masing atau di tempat olahraga yang telah ditentukan. la juga terkadang mengombinasikannya dengan melakukan olahraga yang terpimpin. Apa yang dirasakan oleh Nindya juga dirasakan oleh Alfandi (20 tahun) yang merupakan salah seorang mahasiswa IPDN. Artinya, kebijakan pemerintah secara umum dan kebijakan perkuliahan secara khusus tidak berdampak pada kesehatannya karena olah raga memang telah menjadi bagian dari rutinitas mahasiswa di kampus IPDN, sehingga mau tidak mau mereka harus mengikutinya.

\section{Strategi Menjaga Imun}

Pencegahan penularan Covid-19 adalah dengan menerapkan perilaku hidup bersih dan sehat, seperti mencuci tangan, mengonsumsi makanan bergizi, berolah raga secara rutin, dan beristirahat yang cukup (Karo 2020:1). Bagi mereka yang telah terlanjur terinfeksi Covid-19, mereka melakukan tindakan kuratif. Rio (20 tahun) mengakui pernah terkena Covid-19 karena tidak mematuhi protokol kesehatan saat beraktivitas. Gejala yang dirasakan berupa batuk, sesak napas, demam, indra penciuman dan indra perasa juga tidak berfungsi. la mengikuti anjuran pemerintah dengan melakukan isoman (isolasi

\footnotetext{
${ }^{8}$ Screen time adalah durasi waktu harian yang dihabiskan untuk menatap layar saat perkuliahan.
} 
mandiri) selama 14 hari, dan selama proses isoman ia melakukan aktivitas olahraga di rumah, berjemur dan mengomsumsi suplemen vitamin. Berbeda dengan Rio, Agus (20 tahun) terinfeksi Covid-19 sebanyak dua kali, dan ia mengisolasi dirinya di rumah sekaligus mengomsumsi rempah-rempah tradisional yang dipercaya dapat menyembuhkan Covid-19, seperti jahe, kunyit dan bawang putih. Adnan (21 tahun) juga pernah terinfeksi Covid-19 dengan gejala demam dan hilangnya indra perasa dan penciuman. la mengisolasi dirinya selama dua minggu dan setiap hari mengomsumsi jahe, kunyit merah, dan madu.

Bagaimana mahasiswa yang tidak pernah terinfeksi Covid-19 menjaga imunitas tubuh mereka? Strategi yang dilakukan oleh mahasiswa untuk menjaga dan meningkatkan imunitas tubuh mereka adalah dengan menerapkan pola hidup sehat; mengelola stress; dan mengonsumsi suplemen vitamin.

\section{Pola Hidup Bersih dan Sehat}

Dalam penerapan pola hidup bersih dan sehat (PHBS) terdapat beberapa langkah yang dapat ditempuh demi menjaga dan meningkatkan imunitas tubuh, yaitu 1) Dengan memperbanyak makan sayur dan buah. Hal ini karena vitamin dan mineral yang terkandung dalam sayur dan buah (yang kaya akan vitamin dan mineral) mampu memperkuat sistem kekebalan tubuh dalam melawan virus dan bakteri penyebab penyakit; 2) Beristirahat yang cukup. Hal ini penting untuk mencukupi kebutuhan tidur. Umumnya orang dewasa membutuhkan waktu tidur antara tujuh dan delapan jam, dan remaja membutuhkan waktu tidur antara sembilan dan sepuluh jam; 3) Mengelola stres agar terhindar dari penurunan fungsi kekebalan tubuh; 4) Berolahraga secara rutin paling sedikit 30 menit setiap hari, seperti jogging untuk meningkatkan sistem kekebalan tubuh dan melawan infeksi; dan 5) Menghindari rokok dan alkohol karena asap rokok dan alkohol dapat merusak sistem kekebalan tubuh ${ }^{9}$ (lihat Gambar 2). Bagaimana pola hidup sehat mahasiswa untuk menjaga imunitas tubuh mereka? Pola hidup sehat yang diterapkan mahasiswa untuk menjaga imunitas tubuh mereka mencakup mengonsumsi makanan bergizi, mengonsumsi banyak air putih, menjaga kebersihan, beristirahat, dan berolah raga.

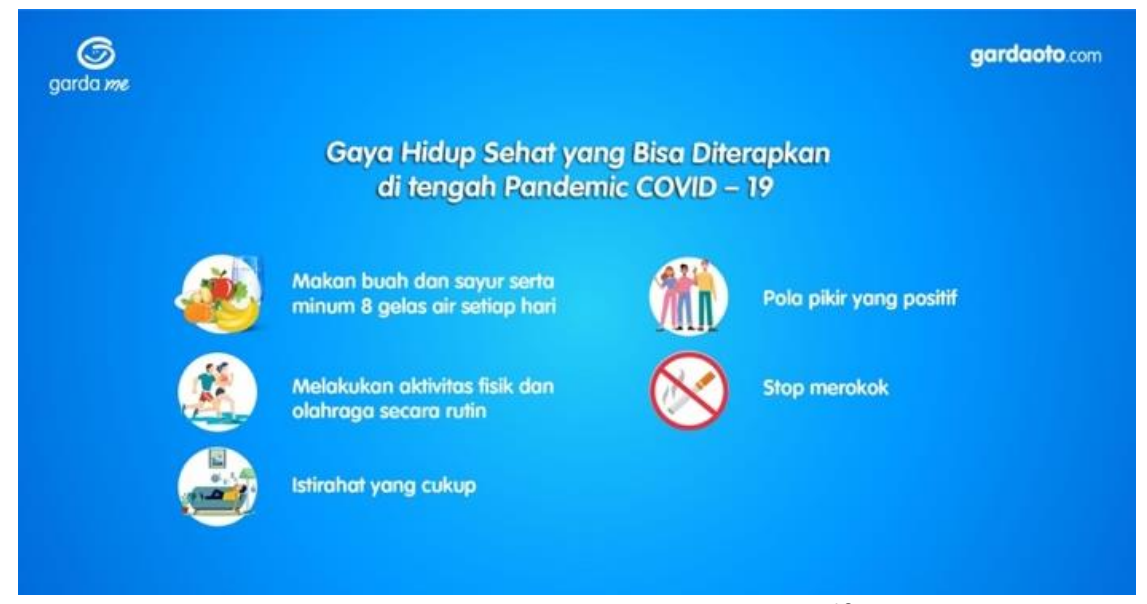

Gambar 2. Poster Pola Hidup Sehat ${ }^{10}$

\footnotetext{
${ }^{9}$ https://www.gardaoto.com/blog/gaya-hidup-sehatyang-bisa-diterapkan-di-tengah-pandemic-covid-19, diakses tanggal 26 November 2021.
} ${ }^{10} \mathrm{https}: / /$ www.gardaoto.com/blog/gaya-hidup-sehat-
$\frac{\text { yang-bisa-diterapkan-di-tengah-pandemic-covid-19 }}{\text { diakses tanggal } 26 \text { November } 2021 .}$ 
Salah satu upaya yang dilakukan oleh Hendra (22 tahun) yang terkait dengan pola hidup sehat adalah dengan mengonsumsi makanan yang bergizi. Makanan bergizi yang dikonsumsinya adalah makanan yang mengandung protein, vitamin, mineral dan antioksidan, seperti telur, daging sapi maupun daging ayam; dan sayur-sayuran hijau, seperti brokoli, bayam dan tomat. Tak hanya itu, Hendra juga mengonsumsi susu sebagai penunjang proses pembentukan energi atau metabolisme pada tubuhnya. Hal rupa juga diterapkan oleh Asmilia (22 tahun), seorang mahasiswi yang di saat pandemi Covid-19 lebih mengatur pola makannya. Demi menjaga dan meningkatkan imunitas tubuhnya, ia rutin mengomsumsi buahbuahan segar setiap harinya, seperti apel, pisang dan jeruk. Selain itu, kebiasaan memakan makanan cepat saji, seperti mie instant ia kurangi dan mengutamakan makan makanan berat, seperti nasi. Tak hanya itu, ia juga menghindari minuman bersoda yang mengandung banyak gula.

Selain mengonsumsi makanan yang bergizi, mengonsumsi banyak air putih juga merupakan pola hidup sehat lainnya yang digunakan oleh mahasiswa dalam kaitan dengan pola hidup sehat. Sri (20 tahun), misalnya, mengemukakan bahwa minum air putih yang cukup juga menjadi hal yang penting untuk dilakukan di masa pandemi untuk menghindari dehidrasi yang dapat menganggu sistem kekebalan tubuh. Pentingnya mengomsumsi air putih dimasa pandemi juga diterapkan oleh Miswar (22 tahun). Sebagai seorang mahasiswa yang memiliki rutinitas olahraga, ia banyak mengomsumsi air putih untuk menjaga dan mengoptimalkan stamina tubuhnya.
Pola hidup sehat yang dikemukakan oleh Bambang (22 tahun) berkaitan dengan kebersihan tubuh dan kebersihan makanan yang dikonsumsi. Untuk kebersihan tubuh, ia rajin mandi, terutama setelah keluar rumah, menjaga kebersihan tangannya karena tangan banyak digunakan untuk berbagai hal, sehingga dapat menjadi media transmisi virus. Untuk kebersihan makanan yang dikonsumsi, ia menghindari mengonsumsi makanan dari luar, termasuk mengonsumsi makanan siap saji. Menurutnya makanan dari luar bisa saja terkontaminasi oleh virus ataupun bakteri, bukan saja dari sisi proses pembuatannya, tapi juga dari sisi pengantarannya. Kebersihan merupakan hal penting yang perlu diperhatikan di saat pandemi, Sri (21 tahun) membiasakan untuk selalu mencuci tangan menggunakan sabun maupun handsanitizer. Kebersihan lingkungan juga tidak luput dari perhatiannya, yaitu dengan menyemprot disinfektan pada permukaan benda yang berada di sekitarnya.

Upaya lainnya dalam kaitan dengan penerapan pola hidup sehat adalah dengan menjaga waktu istirahat. Di tengah pandemi Covid-19, tidur yang cukup sangat memengaruhi sistem kekebalan tubuh. Hendra (22 tahun), misalnya, mengemukakan bahwa di masa pandemi Covid-19, ia menjaga waktu istirahatnya. Di tengah kesibukan sebagai seorang mahasiswa yang memiliki banyak aktivitas yang menguras tenaga dan waktu ia tetap menjaga waktu tidurnya. Ini dilakukannya agar ia selalu fit dalam beraktivitas dan tidak mudah dimasuki virus. Hal serupa dikemukakan oleh Zainal (23 tahun) yang selalu berusaha untuk menyeimbangkan antara waktu beraktivitas dan waktu istirahatnya karena menurutnya orang yang kurang beristirahat akan 
rentan terhadap berbagai penyakit infeksi, termasuk Covid-19.

Daya tahan tubuh yang kuat menjadi salah satu benteng dalam menangkal virus, termasuk Covid-19. Hal ini dapat diantisipasi dengan rajin berolahraga. Menurut Zenko (dalam Asri dan Octaviana 2021:57-58), olahraga adalah faktor penting dalam rumus pola hidup sehat. Miswar (22 tahun) memfokuskan dirinya dengan berolahraga setiap sore sebagai bagian dari pola hidup sehatnya untuk menjaga immunitas tubuhnya. Sebelum pandemi Covid-19, ia hanya berolahraga dua sampai tiga kali seminggu. Tetapi saat pandemi Covid-19, ia konsisten berolahraga setiap sore, dan itu menjadi aktivitas rutin di kampusnya. Hikma (19 tahun) adalah contoh lain yang menjadikan olah raga sebagai bagian dari pola hidup sehatnya. la menyatakan bahwa olahraga sangatlah penting dilakukan di tengah pandemi Covid-19. Dalam kaitan dengan itu, ia melakukan jogging setiap harinya sebagai bagian dari pola hidup sehat agar terhindar dari Covid-19. Hal serupa juga dilakukan oleh Asmilia
(22 tahun), seorang mahasiswi yang mengaku mengalami perubahan aktivitas olahraga selama masa pandemi Covid-19. Dulunya olahraga menjadi hal yang sangat jarang ia lakoni, tetapi dimasa pandemi ini ia menjadikan olahraga sebagai aktivitas rutin yang dilakukan 2-3 kali seminggu.

\section{Mengelola Stres}

Stres merupakan bagian dari proses adaptasi terhadap persoalan atau perubahan dalam hidup. Manusia dapat menghadapi stres dengan dua hasil yang berbeda, yakni menguntungkan atau merugikan. Stres dapat menjadi hal yang menguntungkan apabila orang dapat melakukan adaptasi dengan baik terhadap penyebab stres. Namun, stres dapat menjadi hal yang merugikan apabila gagal dihadapi sehingga dapat menimbulkan penderitaan ataupun gangguan kejiwaan. ${ }^{11}$ Oleh karenanya, stres harus dikelola dengan baik agar tidak menimbulkan dampak yang lebih serius (lihat Gambar 3).

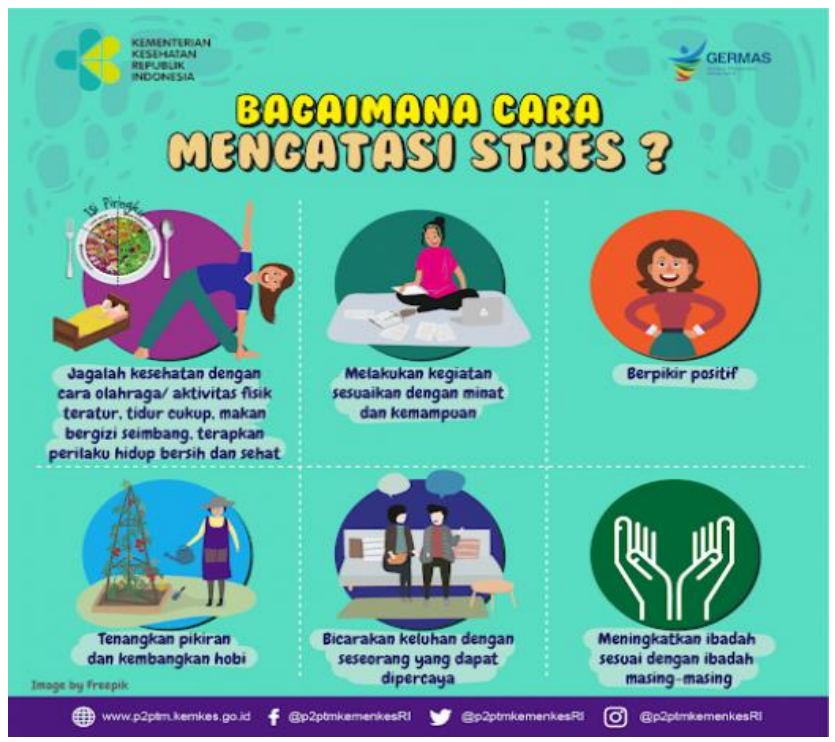

Gambar 3. Poster Cara Mengatasi Stres ${ }^{12}$

${ }^{11}$ Cara Mengelola Stress saat Pandemi - RSUD dr. Mohamad Soewandhie (surabaya.go.id), diakses tanggal 29 November 2021.
12 https://fikes.upnvj.ac.id/id/beritaumum/2021/01/menjaga-kesehatan-danmeningkatkan-imun-didalam-tubuh-di-masa- 
Menurut Schafer (2000:15) mengelola stres adalah suatu program untuk melakukan mengetahui teknik-teknik mengelola stres, sehingga orang lebih baik dalam menangani stress dalam kehidupan. Bagaimana strategi mahasiswa dalam mengelola stress yang dihadapinya? Dua hal yang dilakukan mahasiswa untuk mengatasi stress, yakni: pertama, selalu beraktivitas yang positif; kedua menghabiskan waktu dengan keluarga.

Dalam kaitan dengan aktivitas positif di masa pandemi Covid-19, Sri (21 tahun), misalnya, lebih banyak menghabiskan waktunya untuk melakukan aktivitas-aktivitas yang positif, seperti membersihkan rumah, membantu orang tua, belajar memasak dan lebih memperbanyak ibadah. Hal serupa juga dirasakan oleh Qausa (21 tahun), bahwa selama dirumahkan ia tidak merasakan jenuh atau bosan karena dengan begitu ia lebih memiliki banyak waktu untuk mengeksplorasi diri berdasarkan potensi diri yang dimilikinya, seperti menulis, yang dimulai dengan mencurahkan segala keluh kesahnya dan beban melalui coretan pada kertas. la juga menggunakan waktunya untuk memunculkan ide-ide kreatif yang produktif, seperti menciptakan lagu. Aktivitas positif juga dilakukan oleh Adnan (21 tahun), selama pandemi ia menghabiskan waktunya untuk berolahraga seperti, push up, sit up, plank. Ini dilakukannya untuk membentuk otot tubuhnya sekaligus mengisi waktu kosong agar terhindar dari pikiran-pikiran negatif yang dapat memengaruhi imunitas tubuhnya.

Menghabiskan waktu bersama keluarga adalah cara lain untuk mengelola stress yang dihadapi mahasiswa. Sri (21 tahun) mengungkapkan bahwa selama kebijakan pembelajaran daring diberlakukan, di luar jam kuliah ia lebih memilih untuk menghabiskan waktu yang berkualitas bersama keluarganya di rumah, seperti bermain dengan adik, membantu adik mengerjakan tugas sekolah ketimbang keluar rumah. Bagi banyak orang aktifitas yang dilakukannya ini adalah suatu hal yang sangat sederhana, tetapi baginya ini merupakan momen kebersamaan bagi keluarga yang sulit didapatkan sebelum pandemi Covid-19. Sebagai mahasiswi yang sebagian waktunya dihabiskan di depan gadget dan laptop, Mutmainna (21 tahun) selalu mengupayakan untuk memiliki waktu bersama keluarga, baik itu sekedar menonton TV bersama, maupun saling bertukar cerita dan ini memberikan kebahagiaan tersendiri baginya dan dapat menghilangkan kepenatan di tengah banyaknya tugas dan padatnya jadwal perkuliahan daring.

\section{Mengonsumsi Suplemen}

Sejak merebaknya pandemi Covid-19 banyak anjuran untuk mengonsumi suplemen atau vitamin sebagai penambah daya tahan tubuh. Selain menerapkan pola hidup sehat, banyak orang memilih untuk mengonsumsi suplemen/vitamin untuk meningkatkan imunitas tubuh. Menurut Corrado dkk. (2020), beberapa kandungan suplemen, seperti echinacea, morinda citrifolia, phylantus, vitamin B6, C, dan vitamin $E$, dapat meningkatkan imunitas atau daya tahan tubuh, dan suplemen yang mengandung echinacea cukup direkomendasikan karena selain mampu meningkatkan sistem kekebalan tubuh, echinacea dipercaya bermanfaat sebagai antivirus, antiradang, dan antioksidan.

Anjuran Organisasi Kesehatan Dunia (WHO) dan kementrian kesehatan untuk menerapkan pola hidup bersih dan sehat (PHBS), 
salah satunya yaitu dengan rajin mengonsumsi suplemen vitamin untuk membantu meningkatkan dan menjaga daya tahan tubuh. ${ }^{13}$ Namun, menurut Lidia (2020), anjuran untuk mengonsumsi suplemen atau vitamin untuk penambah daya tahan tubuh, meskipun tidak sepenuhnya benar, namun vitamin-vitamin (seperti vitamin C) dan multivitamin yang mengandung zat besi dinilai dapat mencegah penularan virus Corona. Oleh karenanya, meskipun ada anjuran seperti itu, masyarakat seharusnya bijak dalam mengonsumsinya. Ini karena suplemen berbeda dengan obat, suplemen tidak ditujukan untuk mengatasi, mendiagnosis, mencegah atau menyembuhkan penyakit. Beberapa suplemen justru mengandung bahan aktif yang memiliki efek biologik dalam tubuh, sehingga hal ini dapat membahayakan jika penggunaannya tidak sesuai dengan kebutuhannya. Mengonsumsi vitamin dan suplemen yang tidak tepat dapat menimbulkan efek yang tidak diharapkan, apalagi jika mengonsumsi obat lain, sehingga terjadi interaksi antar keduanya.

Mengonsumsi suplemen vitamin memang merupakan langkah antisipatif untuk menjaga imun. Beberapa vitamin yang paling direkomendasikan untuk itu adalah vitamin C, zat besi (zinc), dan ekstrak Echinacea purpurea. Ketiganya berperan sebagai imunimodulator, yaitu subtansi dalam tubuh yang dapat memengaruhi sistem imun, dengan menggunakan respon imun atau menekan imun agar tidak bereaksi berlebihan terhadap zat asing. ${ }^{14}$

Syopiana (21 tahun), misalnya, menyatakan bahwa mengonsumsi suplemen vitamin di saat pandemi Covid-19 sangatlah

\footnotetext{
${ }^{13}$ https://fk.ui.ac.id/infosehat/suplemen-alami-bisamenjaga-imun-tubuh/, diakses tanggal 07 Desember 2021.
}

diperlukan untuk menjaga imunitas tubuh. Namun, ia cukup selektif dalam memilih suplemen vitamin karena menurutnya dalam memilih suplemen vitamin sangat perlu untuk mengetahui zat yang terkandung di dalamnya, apakah sesuai dengan yang dibutuhkan oleh tubuhnya atau tidak. Bagi mereka yang diasramakan, seperti di IPDN, suplemen vitamin memang disediakan untuk itu, sehingga Nindya (19 tahun), Alfandi (20 tahun), Qausa (21 tahun) yang merupakan mahasiswa IPDN mengonsumsi suplemen vitamin secara rutin karena mereka memang disuplay setiap bulan untuk itu. Mengonsumsi vitamin juga dilakukan oleh Hendra (22 tahun) sebagai suplemen wajib selama pandemi Covid-19 berupa Imboost tablet-suplemen dengan kandungan echinacea purpurea herb dry extract dan Zn Piccolinate dalam bentuk tablet salut selaput-yang digunakan oleh Hendra untuk meningkatkan daya tahan tubuh dan berfungsi untuk mencegah dari sakit dan mempercepat penyembuhan. Berbeda denagn Rio (20 tahun), ia telah mengonsumsi suplemen vitamin jauh sebelum adanya Covid-19, suplemen vitamin yang dikonsumsinya untuk meningkatkan stamina tubuhnya. Tetapi setelah munculnya Covid-19, ia lebih rutin dan teratur mengonsumsi suplemen vitamin. Namun, menurut Miswar (21 tahun), dalam kondisi pandemi Covid-19 orang seringkali panik karena ketakutan terinfeksi Covid-19, sehingga untuk mencegahnya mereka mengonsumsi suplemen vitamin tanpa mempertimbangkan kandungan dan dosis yang diperlukan, sehingga terkadang suplemen yang dikonsumsi berlebihan. Padahal, ia menyadari bahwa mengonsumsi suplemen vitamin yang berlebihan tidak berdampak baik bagi kesehatan,

\footnotetext{
14

http://rspantisecantigisting.com/index.php/2021/07/22 /pentingnya-minum-suplemen-daya-tahan-tubuhselama-pandemi/, diakses tanggal 01 Desember 2021.
} 
Adaptasi Kebijakan, Dampak Perkuliahan Daring, dan Strategi Mahasiswa...

justru ini dapat menimbulkan over dosis, keracunan, dll.

\section{Kesimpulan dan Rekomendasi}

Kebijakan yang dikeluarkan oleh pemerintah terkait penanggulangan Covid-19 berdampak pada aktivitas-aktivitas mahasiswa. Di tengah pandemi Covid-19 mahasiswa melakukan penyesuaian-penyesuaian sebagai bentuk adaptasi terhadap kondisi yang terjadi dan menggunakan berbagai strategi untuk menjaga immunitas.

Temuan penelitian ini menunjukkan bahwa mahasiswa harus beradaptasi dalam kaitan dengan tiga jenis kebijakan, yakni kebijakan pemerintah, kebijakan perkuliahan, dan kebijakan organisasi. Dalam kaitan dengan kebijakan pemerintah secama umum, maka ini mencakup protokol kesehatan, work from home (WFH), pembatasan sosial berskala besar, dan pemberlakuan pembatasan kegiatan masyarakat (PPKM). Kebijakan ini turut memengaruhi mobilitas mahasiswa, sehingga harus mengadaptasikan diri dalam kaitan dengan berbagai pembatasan yang ditetapkan oleh pemerintah. Untuk yang terkait dengan kebijakan perkuliahan, mahasiswa harus beradaptasi dari pembelajaran luring ke pembelajaran daring dengan segala dinamika dan permasalahannya. Selain itu, mahasiswa juga harus beradaptasi dengan kebijakan organisasi kampus karena pengelolaannya juga diadaptasikan dengan kondisi pandemi.

Pada pelaksanaan pembelajaran daring, dampak yang ditimbulkan berkaitan dengan proses pembelajaran dan kesehatan mahasiswa itu sendiri. Perubahan pembelajaran dari metode luar jaringan (luring) ke metode dalam jaringan (daring), dalam implementasinya menimbulkan sejumlah masalah, yakni kesiapan mahasiswa, interaksi antara mahasiswa dan dosen, penumpukan tugas, dan infrastruktur penunjang pembelajaran yang tidak mamadai. Pembelajaran daring juga berdampak pada kesehatan mahasiswa, baik kesehatan psikologis maupun kesehatan fisik. Jika kesehatan psikis berkaitan dengan stress menghadapi pembelajaran daring, maka kesehatan fisik meliputi gangguan mata dan kekakuan otot karena durasi screen time yang berlebihan dan kurangnya gerak selama perkuliahan daring. Namun perkuliahan daring tidak berdampak signifikan pada kesehatan mahasiswa yang diasramakan karena mereka memiliki rutinitas yang menunjang aktivitas sehari-hari mereka.

Di masa pandemi Covid-19 mahasiswa melakukan berbagai strategi dalam menjaga dan meningkatkan imunitas tubuh, yaitu; menerapkan pola hidup sehat, mengelola stress dan mengonsumsi suplemen vitamin. Strategi pola hidup sehat mencakup mengonsumsi makanan bergizi, mengonsumsi banyak air putih, menjaga kebersihan, beristirahat, dan berolah raga. Strategi pengelolaan stress dilakukan dengan melakukan aktivitas-aktivitas yang positif dan banyak menghabiskan waktu dengan keluarga. Mengonsumsi suplemen vitamin merupakan strategi lainnya untuk menjaga ketahanan tubuh. Jika merujuk pada temuantemuan di atas maka adaptasi dan strategi berpengaruh secara signifikan dalam upaya pencegahan penularan Covid-19.

Dalam implementasi berbagai kebijakan yang dikeluarkan pemerintah, hendaknya dilakukan pemerataan agar tidak terkesan tebang pilih. Dengan kebijakan pembelajaran daring, dukungan terkait dengan sarana yang dibutuhkan karena ada daerah-daerah tertentu yang memiliki jaringan yang buruk (on and off), sehingga mahasiswa kesulitan untuk mengakses kelas daring. Selain itu, tenaga pendidik juga harusnya lebih kreatif dalam proses pembelajaran agar mahasiswa tidak merasa 
Jurnal Emik, Volume 4 Nomor 2, Desember 2021

bosan karena metode pengajaran yang monoton.

\section{Daftar Pustaka}

Adijaya, O. dan Bakti, A. P. 2021. "Peningkatan Sistem Imunitas Tubuh dalam Menghadapi Pandemi Covid-19", Jurnal Kesehatan Olahraga, 9(03):51-60, https://ejournal.unesa.ac.id/index.php/i urnal-kesehatanolahraga/article/view/40767/36302, diakses tanggal 3 November 2021.

Anwar, A.A. dan Tuhuteru, A. 2020. "Ale Rasa Beta Rasa: Covid-19 dan Pembelajaran Daring Mahasiswa FISK IAKN Ambon, EMIK, 3(1):103-120, http://ejournals.umma.ac.id.index.php/ emik/article/view/557, diakses tanggal 1 Desember 2021.

Argaheni, N. B. 2020. "Sistematik review: Dampak Perkuliahan Daring Saat Pandemi Covid-19 terhadap mahasiswa Indonesia". PLACENTUM: Jurnal IImiah Kesehatan dan Aplikasinya, 8(2):99-108, https://doi.org/10.20961/placentum.v8i 2.43008, diakses tanggal 26 November 2021.

Ashadi, K., Andriana, L M., dan Pramono, B. A. 2020. "Pola Aktivitas Olahraga Sebelum dan Selama Masa Pandemi Covid-19 pada Mahasiswa Fakultas Olahraga dan Fakultas Non-Olahraga", Jurnal SPORTIF: Jurnal Penelitian Pembelajaran, 6(3):713-728, https://doi.org/10.29407/js unpgri.v6i3 .14937 , diakses tanggal 11 September 2021.

Asri, N., dan Octaviana, E. S. L. 2021. "Aktivitas Olahraga di Masa Pandemi Covid-19 Terhadap Tingkat Stres Mahasiswa
Pendidikan Olahraga Universitas Islam

Kalimantan Muhammad Arsyad Al Banjari Banjarmasin". Halaman Olahraga Nusantara (Jurnal IImu Keolahragaan), 4(1):53-65, http://dx.doi.org/10.31851/hon.v4i1.52 13, diakses tanggal 28 November 2021.

Asti, E. 2021. "Pengaruh Hubungan Pembelajaran Daring di Era Pandemi Covid-19 Terhadap Mental Peserta Didik", EPISTEMA, 2(2):83-89, https://journal.uny.ac.id/index.php/epis tema/article/view/41351, diakses tanggal 20 November 2021.

Burnet, K., Higgins, S., Kelsch, E., Moore, J. B., dan Stoner, L. 2020. "The effects of manipulation of Frequency, Intensity, Time, and Type (FITT) On Exercise Adherence: A Meta-Analysis", Translational Sports Medicine, 3(3):222234, https://doi.org/10.1002/tsm2.138, diakses tanggal 15 September 2021.

Corrado, D., Magnano, P., Muzii, B., Coco, M., Guarnera, M., De Lucia, S., dan Maldonato, N. M. 2020. "Effects of social distancing on psychological state and physical activity routines during the COVID-19 pandemic". Sport sciences for health, 16(4): 619-624. https://doi.org/10.1007/s11332-02000697-5, diakses tanggal 10 Desember 2021.

Damayanthi, U. 2020. “Efektivitas Pembelajaran Daring di Masa pandemic Covid-19 pada Perguruan Tinggi Keagamaan Katolik," Edutech: Jurnal Educational Technology, 19(3):

241-262, https://ejournal.upi.edu/index.php/edu tech/article/view/26978/pdf, diakses tanggal 20 Oktober 2021. 
Adaptasi Kebijakan, Dampak Perkuliahan Daring, dan Strategi Mahasiswa...

Farah, B., dan Nasution, R. D. 2020. "Analisis

Perubahan Orientasi Pola Hidup Mahasiswa Pasca Berakhirnya Masa Pandemic Covid-19". Jurnal Noken: IImuIlmu Sosial, 5(2):23-36, https://doi.org/10.33506/jn.v512.968, diakses tanggal 13 September 2021.

Furkan, F., Rusdin, R., dan Shandi, S. A. 2021. "Menjaga Daya Tahan Tubuh Dengan Olahraga Saat Pandemi Corona Covid19", JISIP: Jurnal IImu Sosial dan pendidikan), 5(1):424-430, https://doi.org/10.36312/jisip.v5il.1748, diakses tanggal 3 Novemver 2021.

Gumantan, A., Mahfud, I., dan Yuliandra, R. 2020. "Tingkat Kecemasan Seseorang Terhadap Pemberlakuan New Normal dan Pengetahuan Terhadap Imunitas Tubuh", Sport Science and Education Journal, 1(2):18-27, https://doi.org/10.33365/ssej.vli2.718, diakses tanggal 21 September 2021.

Hasanah, U..; Ludiana; Immawati; dan Livana. 2020. “Gambaran Psikologis Mahasiswa Dalam Proses Pembelajaran Selama Pandemi Covid-19", Jurnal Keperawatan Jiwa, Agustus, 8(3):299-306.

Kahfi, A. 2021. "Dampak Pembelajaran Daring di Masa Pandemi Covid-19 Terhadap Perkembangan Kognitif Anak", Dirasah, Februari, 4(1):14-23, https://staibinamadani.e-journal.id/jurdir, diakses tanggal 15 November 2021.

Karo, M. B. 2020. "Perilaku Hidup Bersih Dan Sehat (PHBS) Strategi Pencegahan Penyebaran Virus Covid-19." Prosiding Seminar Nasional Hardiknas (1):1-4, http://proceedings.ideaspublishing.co.id /index.php/hardiknas/article/view/1, diakses tanggal 5 November 2021.
Khasanah, D. R. A. U., Pramudibyanto, H., dan Widuroyekti, B. 2020. "Pendidikan Dalam Masa Pandemi Covid-19", Jurnal Sinestesia, 10(1):41-48, https://sinestesia.pustaka.my.id/journal Larticle/view/44, diakses tanggal 5 November 2021.

Kurniawati, J., dan Baroroh, S. 2016. "Literasi Media Digital Mahasiswa Universitas Muhammadiyah Bengkulu":, Jurnal Komunikator, 8(2):51-66, http://journal.umy.ac.id/index.php/jkm /article/view/2069 diakses tanggal 31 Oktober 2021.

Lidia, K. 2020. "Peningkatan Kesehatan dengan Suplemen dan Gizi Seimbang di Era Pandemi Covid-19", Jurnal Pengabdian kepada Masyarakat LPPM Undana, 14(2):63-68, https://ejurnal.undana.ac.id/index.php/i Ippm/article/view/3445, diakses tanggal 27 Oktober 2021.

Luzi, L., dan Radaelli, M. G. 2020. "Influenza and Obesity: Its Odd Relationship and the Lessons for Covid-19 Pandemic", Acta Diabetologica, 57(6):759-764, https://doi.org/10.1007/s00592-02001522-8, diakses tanggal 13 September 2021.

Ningsih, S. 2020." Persepsi Mahasiswa Terhadap Pembelajaran Daring Pada Masa Pandemi Covid-19". JINOTEP (Jurnal Inovasi Dan Teknologi Pembelajaran): Kajian Dan Riset Dalam Teknologi Pembelajaran, 7(2):124-132, https://:doi.org/10.17977/um031v7i220 20p124, diakses tanggal 26 November 2021.

Nugroho, S. H. P., Umma, N., Lianawati, N., Pornomo, H., dan Kusumawati, G. R. 
Jurnal Emik, Volume 4 Nomor 2, Desember 2021

2021. "Kesiapan Adaptasi Kebiasaan Baru Pencegahan Penularan Covid 19". ABDIMAS: Jurnal Pengabdian Masyarakat, 4(1):578-583, https://doi.org/10.35568/abdimas.v4il.2 24, diakses tanggal 3 November 2021.

Pustikasari, A. dan Fitriyanti, L. 2021. "Stress dan Zoom Fatique pada Mahasiswa Selama Pembelajaran Daring di Masa Pandemi Covid-19", Jurnal Ilmiah Kesehatan, 13(1):25-37, http://journal.thamrin.ac.id/index.php/j ikmht/article/view/467/491, diakses tanggal 18 November 2021.

Sadikin, A., dan Hamidah, A. 2020. "Pembelajaran Daring di Tengah Wabah Covid-19 (Online Learning in the Middle of the Covid-19 Pandemic)". Biodik, 6(2):214-224, https://respository.unja.ac.id/id/eprint/ 15758, diakses tanggal 30 November 2021.

Schafer, W.E. 2000. Stress Management for Wellness. USA: Harcourt College Publishers.

Sofyana, L. dan Rozak, A. 2019. "Pembelajaran Daring Kombinasi Berbasis Whatsapp Pada Kelas Karyawan Prodi Teknik Informatika Universitas PGRI Madiun", Jurnal Nasional Pendidikan Teknik Informatika 8(1):81-86, https://www.researchgate.net/publicati on/334247053 PEMBELAJARAN DARIN G KOMBINASI BERBASIS WHATSAPP $P$ ADA KELAS KARYAWAN PRODI TEKNI K INFORMATIKA UNIVERSITAS PGRI M ADIUN, diakses tanggal 21 Oktober 2021.

Syafrida, S., dan Hartati, R. 2020. "Bersama Melawan Virus Covid-19 di Indonesia". SALAM: Jurnal Sosial Dan
Budaya Syar-I, 7(6):495-508, https://doi.org/10.15408/sjsbs.v7i6.153 25, diakses tanggal 8 November 2021.

Wijayanti, M., Yunita, T., dan Dharmanto, A. 2020. "Pembelajaran Perguruan Tinggi Dalam Jaringan (Daring) Masa Pandemi Covid-19.", Jurnal Kajian IImiah, 1(1):3138 , https://doi.org/10.31599/jki.v1i1.268, diakses tanggal 5 November 2021.

Wong, A. Y. Y., Ling, S. K. K., Louie, L. H. T., Law, G. Y. K., So, R. C. H., Lee, D. C. W., Yau, F. C. F., dan Yung, P. S. H. 2020. "Impact Of The COVID-19 Pandemic on Sports and Exercise", Asia-Pacific Journal of Sports Medicine, Arthroscopy, Rehabilitation and Technology, 22:39-44, https://doi.org/10.1016/i.asmart.2020.0 7.006, diakses tanggal 10 September 2021.

Zaenudiin, M., Asiah, D. H. S., Santoso, M. B., dan Rifai, A. A. 2021. "Perubahan Perilaku Masyarakat Jawa Barat Dalam Melaksanakan Adaptasi Kebiasaan Baru Di Masa Pandemi Covid-19". Share: Social Work Journal, 11(1):1-12, https://doi.org/10.24198/share.v11i1.3 1681, diakses tanggal 15 September 2021. 